\title{
FSA contributions 5: Buxaceae
}

\author{
H.F. GLEN*
}

Monoecious evergreen shrubs or small trees. Leaves opposite, simple, shortly petiolate, entire; stipules 0 . Inflorescences compact axillary racemes or cymes, sessile or shortly pedicelled. Flowers radially symmetrical, unisexual, small; perianth of 2 sepaloid whorls. Male flowers: perianth lobes 4 , imbricate; stamens 4-8, opposite perianth lobes, filaments free, anthers dorsifixed near base, 2-thecous. Female flowers: perianth lobes 4-6, imbricate; ovary superior, 3-locular with 2 pendulous ovules per locule, styles 3, usually distant. Fruit a loculicidal, 3-horned capsule. Seeds glossy black, triangular in section.

A mainly northern hemisphere family of four genera and about 100 species. One genus with two species occurs naturally within the area of the Flora of southern Africa. In addition species of the genera Sarcococca, Pachysan$d r a$ and Simmondsia (this last often regarded as constituting a separate family) are sometimes cultivated here.

4533000 BUXUS

Buxus L., Species plantarum 983 (1753); Hutch.: 375 (1915); Marloth: 142 (1925); Hutch.: 108 (1967); R.A.Dyer : 326 (1975). Type species: B. sempervirens L.

Buxella Tiegh.: 326 (1897). No type cited.

Notobuxus Oliv.: t. 1400 (1882); Hutch.: 376 (1915); E.Phillips: 138 (1943); E.Phillips: 470 (1951). Type species: N. natalensis Oliv.

Description as for family.

1a Bark longitudinally fissured, greenish brown: twigs angled; leaves $12-40 \times 6-18 \mathrm{~mm}$, apex obtuse . 1. B. macowani Ib Bark rough, pale brown; twigs grooved; leaves $50-100 \times$ 20-50 mm; apex with a drip tip ........ 2. B. natalensis

A mainly north temperate genus of some 80 species, two of which occur naturally in our area. In addition, $B$. sempervirens is occasionally cultivated here; PRE has specimens from Tokai (Western Cape), Cedara (KwazuluNatal) and Roodeplaat (Gauteng).

Friis (1989) discusses the generic delimitation of the African species in some detail, and supports the conclusion that while Notobuxus is a good subgenus, it cannot be recognised as generically distinct from Buxus.

1. B. macowanii Oliv in Hooker's Icones plantarum 16: t. 1518 (1886); Sim: 321 (1907); Hutch.: 55 (1912); Hutch.: 375 (1915); Palmer \& Pitman: 1183 (1973); E.S.Pooley: 238 (1993). Type: Kwelegha Forest, Hutchins

\footnotetext{
"National Herbarium, Private Bag X101, Pretoria 0001 MS received: 1994-02-08.
}

in MacOwan (Herbarium Normale Austro-Africanum) 916 (K, lecto., here designated; BOL!, NBG!, isolecto.).

Buxella macowanii (Oliv.) Tiegh.: 326 (1897).

Notobuxus macowanii (Oliv.) E.Phillips: 140 (1943).

Tree 4-9 m tall, \pm glabrous; stem straight, slender; bark greenish brown, longitudinally fissured; branchlets angled. Leaves opposite, narrowly rhombic-elliptic to ovate-oblong, 12-40 ×6-18 mm, apex obtuse, sometimes minutely apiculate, base cuneate, stiffly coriaceous, dark green, shiny; in seedlings and juvenile specimens leaves very narrowly linear. Inflorescences \pm sessile axillary raceme; flowers very small, greenish. Male flowers clustered at base; perianth lobes 4; stamens 4-6, filaments free; pistillode minute. Female flowers apical or on separate inflorescences; perianth lobes 4-6; ovary 3-locular; styles 3. Fruit a loculicidal, 3-horned, greenish brown capsule, $\pm 7 \mathrm{~mm}$ in diameter. Seeds glossy black, triangular in section, $\pm 5.0 \times 2.5 \times 2.5 \mathrm{~mm}$. Flowering July-October; fruiting February to June. Figure 1.

Widespread from Eastern Cape to the North-West Province and Mpumalanga (Eastern Transvaal). Figure 2.

Vouchers: Abbott 87; W.F. Barker 10902; Codd 10512; G.K. Theron 2161: HJ.T. Venter 5226

Oliver (1886) records in the protologue that this species is described from several gatherings made by Hutchins, and sent to Kew by MacOwan. This implies the existence of several syntypes, none of which is specified precisely. Hutchinson (1912) mentions only one of these, namely Hutchins in MacOwan 916. This implicit acceptance of this specimen as lectotype is here made explicit.

Sterile plants of this species are similar in habit and leaf size and arrangement to Carissa bispinosa (L.) Desf. ex Brenan, but the latter has conspicuous branched thorns, whereas Buxus species are unarmed. The leaves of $B$. sempervirens are similar in size and shape to those of $B$. macowanii, but in the exotic species the midribs and a marginal vein are much more prominent, especially beneath:

The Xhosa name garagara is recorded for this species by Oliver (1886); the specimen Archibald 5409 (BOL) gives the alternative spelling gala-gala. Palmer \& Pitman (1973) record, in addition to the other common names noted in this paragraph, the names Buig-my-nie (Afrikaans), umGalagala and umNgquzu (Zulu). The specimen $F$. Venter 2000 (PRE) records the Tswana common name mupshane. Marloth (1925) gives the common name Cape box, noting that the wood of Gonioma kamassi E.Mey. was exported under the same name. He records that the wood of Buxus macowanii is almost as suitable for making woodcuts for printing as that of the European $B$. sempervirens, but that logs are inclined to split while drying. 


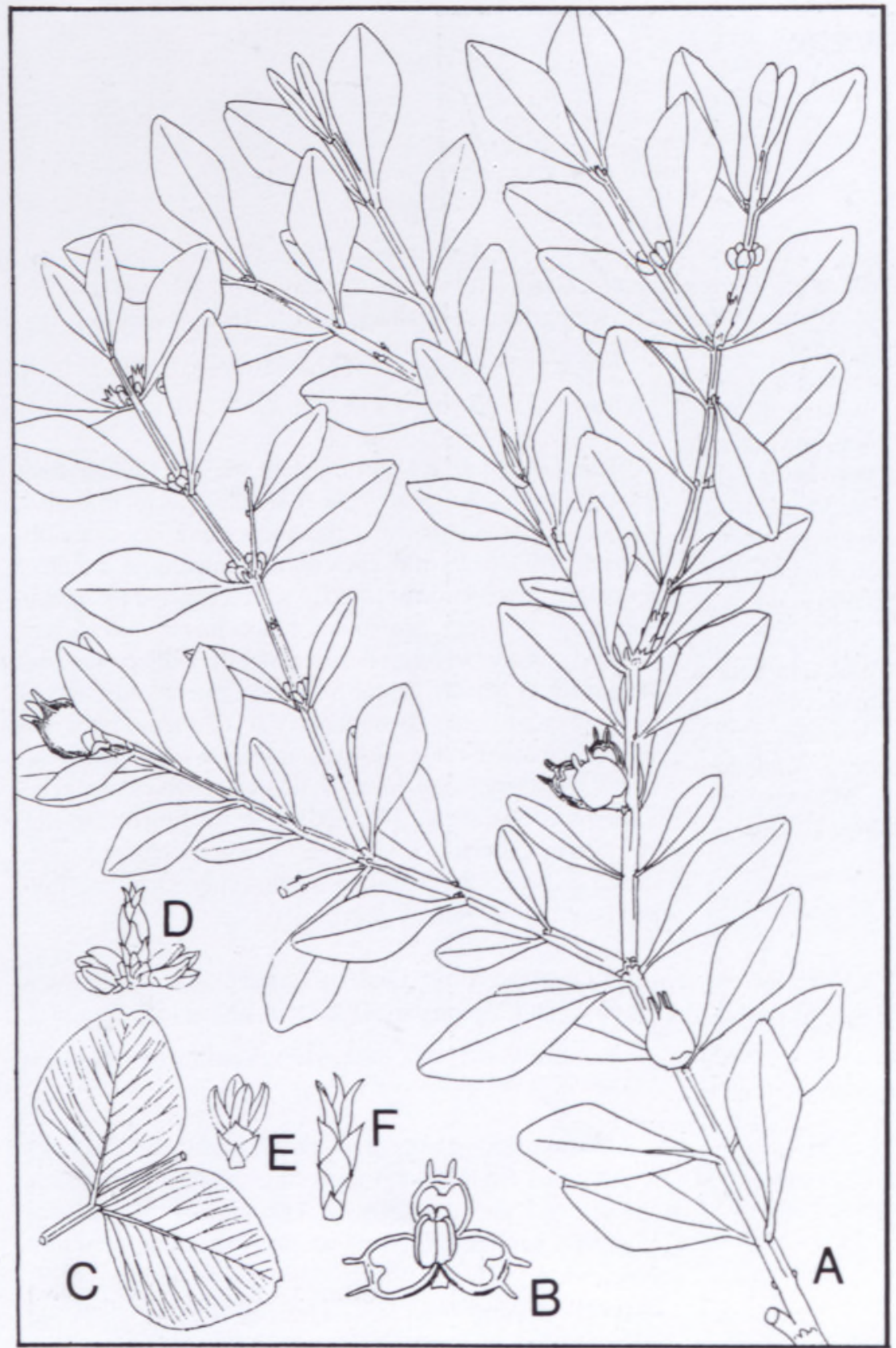

FIGURE 1.-Buxus macowanii Oliv.: A, branch $\times 0.9$; $B$, open capsule, $\times$ 0.9 ; C, broad-leaved form, $\times 0.9$; $D$, cluster of one female and two male flowers, $\times 2.5$; E, male flower, $\times 4.3 ; \mathrm{F}$, female flower, $\times$ 4.3. Taken from Sim (1907).

In the National Tree List (Von Breitenbach 1995) this tree is No. 358, with standard names Kaapse buksboom and Cape Box.

Although the first published record of this species dates from 1886 , the first written account of it known to the present author is some 60 years older. This is a curious handwritten account by C.H. Wehdemann (see entry under this name in Gunn \& Codd 1981) of a group of trees on a farm near Somerset East, Eastern Cape. This account forms part of a set dated 1 August 1826; if Wehdemann had published his notes, this tree would have quite a different name today.

2. B. natalensis (Oliv.) Hutch., Genera of flowering plants 2: 108 (1967); Palmer \& Pitman 2: 1185 (1973); E.S.Pooley 238 (1993). Syntypes: Natal, Inanda, Wood 1357 (NH, K, BOL!); Natal, Tongaat, Cooper 3465 (K).

Notobuxus natalensis Oliv.: t. 1400 (1882); Sim: 320 (1907); Hutch.: 55 (1912); Hutch.: 376 (1915).
Shrubs or small trees $1-3(-5) \mathrm{m}$ tall, \pm glabrous; main stem straight, slender; bark rough, pale brown; young

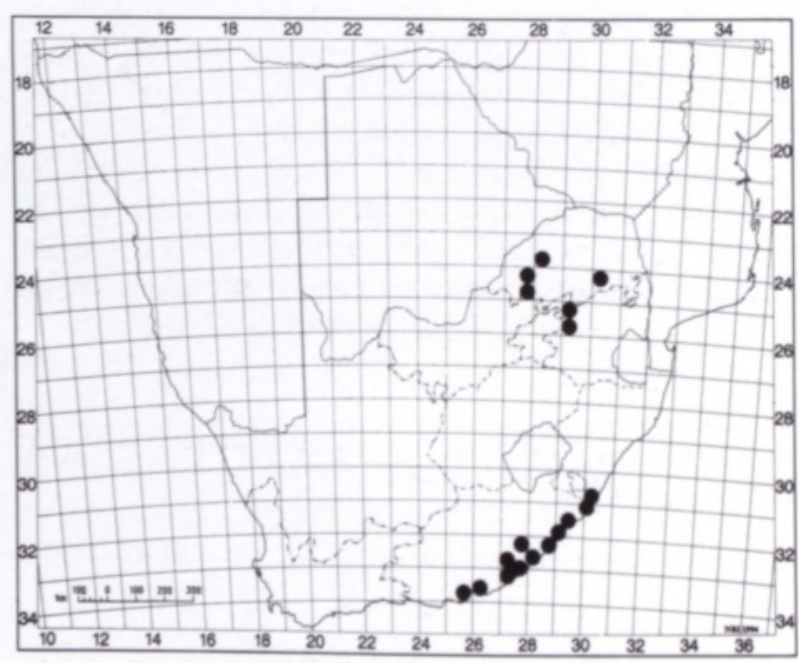

FIGURE 2.-Distribution of Buxus macowanii Oliv. 


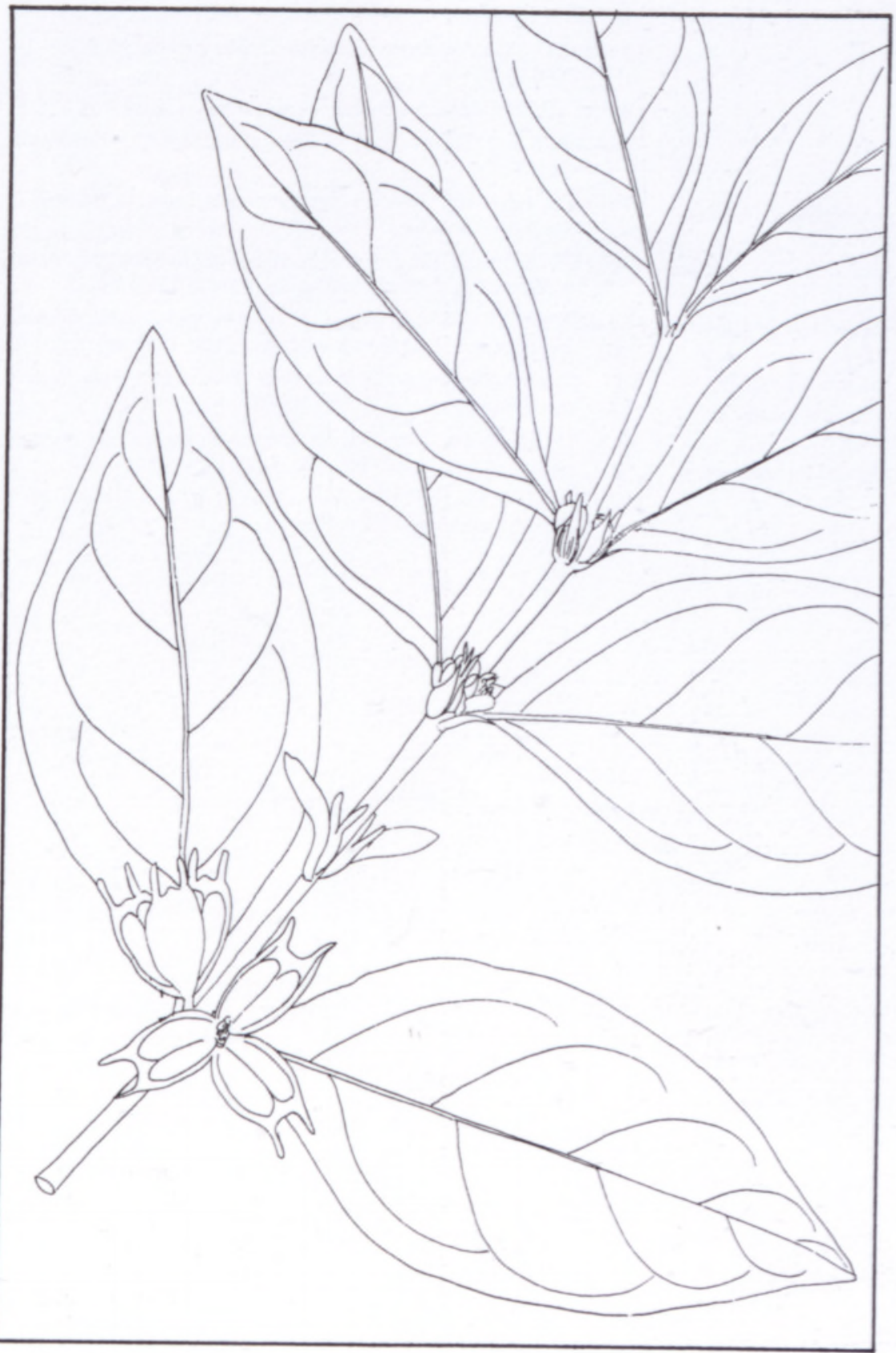

FIGURE 3.-Buxus natalensis (Oliv.) Hutch: branch with flowers and fruit, $\times 0.9$.

stems bright green, grooved. Leaves opposite, shortly petiolate, elliptic, $50-120 \times 20-50 \mathrm{~mm}$, apex with a driptip, base cuneate; midrib prominent below; thinly coriaceous, dark green, shiny; petiole $2-6 \mathrm{~mm}$ long. Inflorescences \pm sessile axillary clusters with both male and female flowers; flowers small, white, pale grey, green or yellow. Male flowers: perianth lobes 4; stamens 4-8, filaments free; pistillode minute. Female flowers: perianth lobes 4-6; ovary 3-locular; styles 3. Fruit a loculicidal, 3-horned, greenish brown capsule, $\pm 12 \mathrm{~mm}$ in diameter. Seeds glossy black, triangular in section, $\pm 7 \times 3 \times 3 \mathrm{~mm}$. Flowering August-September; fruiting September-December. Figure 3.

Endemic to KwaZulu-Natal and adjacent Transkei, mostly coastal. Figure 4 .

Vouchers: Abbott 214; A.W. Bayer 767; C.J. Wand 7153; Wells 3502; White 10631 .

Palmer \& Pitman (1973) record the common names Natal box, iGalagala and ukuXeza (Xhosa), umGalagala,
umHlulambazo, umPhicamaguma and umMgquzu (Zulu) for this tree. In the National Tree List (Von Breitenbach

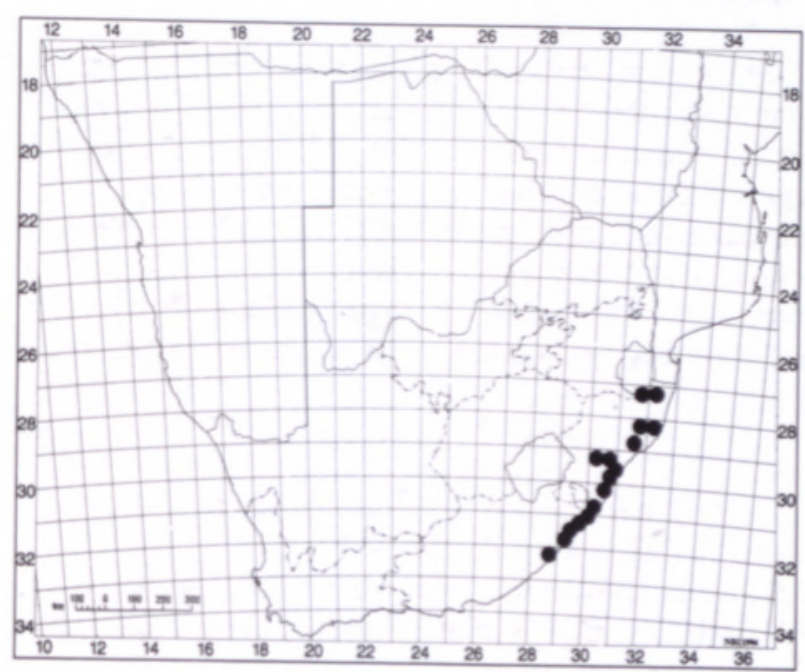

FIGURE 4,-Distribution of Buxus natalensis (Oliv.) Hutch. 
1995) this is No. 359, with standard names Natalse Buksboom and Natal Box.

\section{REFERENCES}

DYER, R.A. 1975. Genera of South African flowering plants 1. Government Printer, Pretoria.

FRIIS, I. 1989. A synopsis of the Buxaceae in Africa south of the Sahara. Kew Bulletin 44: 293-299.

GUNN, M.D. \& CODD, L.E. 1981. Botanical exploration of southern Africa. Balkema, Cape Town.

HUTCHINSON, J. 1912. African Buxeae. Kew Bulletin 1912: 52-55.

HUTCHINSON, J. 1915. Buxus and Notobuxus (Euphorbiaceae). Flora capensis 5,2: 375-377. Lovell Reeve, London.

HUTCHINSON, J. 1967. Genera of flowering plants. Clarendon Press, Oxford.

LINNAEUS, C. 1753. Species plantarum 1. Salvii Holmiae.
MARLOTH, H.W.R. 1925. Flora of South Africa. Darter, Cape Town.

OLIVER, D. 1882. Notobuxus natalensis. Hooker's Icones plantarum 14: 78, t. 1400 .

OLIVER, D. 1886. Buxus macowanii. Hooker's Icones plantarum 16: t. 1518.

PALMER, E. \& PITMAN, N. 1973. Trees of southern Afriea. Balkema, Cape Town.

PHILLIPS, E.P. 1943. Some changes in nomenclature IV. Journal of South African Botany 9: 137-140.

PHILLIPS, E.P. 1951. The genera of South African flowering plants, edn 2. Memoirs of the Botanical Survey of South Africa No. 25.

POOLEY, E.S. 1993. The complete field guide to trees of Natal, Zululand and Transkei. Natal Flora Publications Trust, Durban.

SIM, T.R. 1907. The forests and forest flora of the Colony of the Cape of Good Hope. Taylor \& Henderson, Aberdeen.

VAN TIEGHEM, Ph. 1897. Sur les Buxacées. Annales des sciences naturelles, botanique, Paris, Sér. 8, 5,5: 289-338.

VON BREITENBACH, F. 1995. National list of indigenous trees, edn 3. Dendrological Foundation, Pretoria. 